\title{
Correction for temporal trends in respirable dust and respirable quartz concentrations within the European industrial minerals sector over a 15-year period (2002-2016)
}

Zilaout H, Houba R, Kromhout H. Temporal trends in respirable dust and respirable quartz concentrations within the European industrial minerals sector over a 15 -year period (20022016). Occupational and Environmental Medicine 2020; 77:268-275.

In the published version the unit got inadvertently deleted in this sentence:

"Geometric mean respirable quartz concentrations per job per site per campaign varied even more at four orders of magnitude from 0.1 to $1 \mathrm{mg} / \mathrm{m}^{3}$ (figure $2 \mathrm{~B}$ )."

Correct sentence should be:

"Geometric mean respirable quartz concentrations per job per site per campaign varied even more at four orders of magnitude from $0.1 \mu \mathrm{g} / \mathrm{m}^{3}$ to $1 \mathrm{mg} / \mathrm{m}^{3}$ (figure $2 \mathrm{~B}$ ).”. The latter is the correct variable that is used in data analysis of this paper.

\section{(2) \\ OPEN ACCESS}

Open access This is an open access article distributed in accordance with the Creative Commons Attribution Non Commercial (CC BY-NC 4.0) license, which permits others to distribute, remix, adapt, build upon this work noncommercially, and license their derivative works on different terms, provided the original work is properly cited, appropriate credit is given, any changes made indicated, and the use is non-commercial. See: http://creativecommons.org/licenses/by-nc/ $4.0 \%$.

(C) Author(s) (or their employer(s)) 2020. Re-use permitted under CC BY-NC. No commercial re-use. See rights and permissions. Published by BMJ.

Occup Environ Med 2020;77:428. doi:10.1136/oemed-2019-106074corr1

D Check for updates 